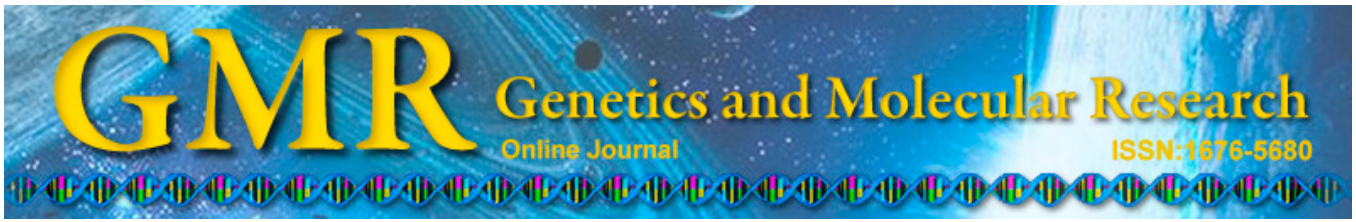

\title{
Genetic control and transgressive segregation of zinc, iron, potassium, phosphorus, calcium, and sodium accumulation in cowpea (Vigna unguiculata) seeds
}

\author{
C.A. Fernandes Santos ${ }^{1}$ and L.S. Boiteux ${ }^{2}$ \\ ${ }^{1}$ Embrapa Semiárido, Petrolina, PE, Brasil \\ ${ }^{2}$ Embrapa Hortaliças, Brasília, DF, Brasil \\ Corresponding author: C.A. Fernandes Santos \\ E-mail: carlos-fernandes.santos@embrapa.br
}

Genet. Mol. Res. 14 (1): 259-268 (2015)

Received July 7, 2014

Accepted November 21, 2014

Published January 16, 2015

DOI http://dx.doi.org/10.4238/2015.January.16.10

\begin{abstract}
Cowpea crop, through combining a range of essential minerals with high quality proteins, plays an important role in providing nutritional security to human population living in semi-arid regions. Studies on genetics of biofortification with essential minerals are still quite scarce, and the major objective of the present study was to provide genetic information on development of cowpea cultivars with high seed mineral contents. Genetic parameters heritability and minimum number of genes were estimated for seed accumulation of zinc ( $\mathrm{Zn})$, iron $(\mathrm{Fe})$, calcium $(\mathrm{Ca})$, phosphorus $(\mathrm{P})$, potassium $(\mathrm{K})$, and sodium $(\mathrm{Na})$. Generation mean and variance analyses were conducted using contrasting parental lines, $\mathrm{F}_{1}, \mathrm{~F}_{2}$, and backcross populations derived from IT97K-1042-3 x BRS Tapaihum and IT97K-1042-3 x Canapu crosses. High narrow-sense heritability $\left(\mathrm{h}^{2}\right)$ values were found for accumulation of Fe (65-86\%), P (74-77\%), and K (77-88\%), whereas moderate $\mathrm{h}^{2}$ values were observed for accumulation of $\mathrm{Ca}$ (41-56\%), $\mathrm{Zn}(51-83 \%)$, and $\mathrm{Na}(50-55 \%)$ in seeds. Significant additive genetic effects as well
\end{abstract}


as parental mean effects were detected in both crosses for all minerals, whereas epistasis was important genetic component in $\mathrm{Zn}$ content. The minimum number of genes controlling the accumulation of minerals ranged from two $(\mathrm{K})$ to $11(\mathrm{P})$. Transgressive segregation was observed in $\mathrm{F}_{2}$ populations of both crosses for all minerals analyzed. The results suggest that, although under either oligogenic or polygenic control, the seed content of these six minerals in cowpea can be improved via standard breeding methods largely used for self-pollinated crops.

Key words: Brazilian semi-arid; Generation mean analyses; Minerals; Variance analyses

\section{INTRODUCTION}

Cowpea [Vigna unguiculata (L.) Walp.] is the most important pulse crop in the Brazilian Semi-arid, a geographic region responsible for $20 \%$ of the global production of this crop species (FAO, 2011). The cowpea crop plays a critical role in providing nutritional security to human population living in tropical semi-arid regions, since it is one of the few available food sources that combines high quality protein and essential minerals (Santos et al., 2012; Santos and Boiteux, 2013).

Human organism requires daily intake of sufficient quantities of minerals such as iron $(\mathrm{Fe})$ and zinc $(\mathrm{Zn})$ in order to maintain its proper metabolic functions (Ribeiro et al., 2008). Deficiency in the supply of essential minerals in the diet affects more than two billion people worldwide, especially in poor rural communities of developing countries (Bouis and Welch, 2010). Thus, introduction of biofortified agricultural products and crop varieties with superior nutritional value is an important low-cost strategy for increasing the food sustainability. In addition, these improved and locally adapted cultivars function as a supplementary component in intervention actions especially in geographic areas under higher risk of nutritional security (Rios et al., 2009).

Extensive evaluations of cowpea germplasm for higher levels of seed/grain minerals have been carried out. Singh (2007) evaluated 50 cowpea lines for a set of four minerals and found that the seed mineral content ranged from 46 to $79 \mathrm{ppm}$ (average $59.4 \mathrm{ppm}$ ) for Fe; 545 to $1330 \mathrm{ppm}$ for calcium (Ca) (average $829 \mathrm{ppm}$ ); 23 to $48 \mathrm{ppm}$ for $\mathrm{Zn}$ (average $38 \mathrm{ppm}$ ), and 12,750 to $16,250 \mathrm{ppm}$ for potassium (K) (average 14,721 ppm). The inbred line IT97K-1042-3 displayed the highest values for Fe (65 ppm) and Zn (46 ppm), and it was considered a major genetic source in breeding programs aiming to increase the nutritional value of cowpea (Singh, 2007). Later, Boukar et al. (2011) screened 1541 cowpea accessions and reported the maximum dry matter seed values for $\mathrm{Ca}, \mathrm{Fe}, \mathrm{Zn}$, phosphorus $(\mathrm{P})$, and $\mathrm{K}$ of $1.395,79.5,58.0$, 6.750 , and $18.450 \mathrm{mg} / \mathrm{kg}$, respectively. This large natural variability in seed mineral content in cowpea germplasm allows employment of conventional breeding strategies to increase the accumulation of these nutrients in seeds of commercial cultivars.

Information about the genetic control of mineral accumulation and genetic biofortification with essential minerals in cowpea seeds is quite scarce. Studies have found monogenic inheritance for $\mathrm{Fe}$ absorption in other crop species such as soybean and tomato (Brown and Wann, 1982). However, few studies have examined the genetic parameters necessary to assist breeding projects with the objective of increasing seed mineral accumulation in elite cowpea 
lines. Estimates of the minimum number of genes controlling accumulation of many essential minerals are not yet available in cowpea. One of the few examples is the study conducted by Ojo et al. (2006) that reported 12 effective factors (genes) controlling P level in cowpea. In common bean (Phaseolus vulgaris), the interaction of alleles at two loci was observed for Fe uptake by plants (Coyne et al., 1982). Additive genetic effect had a greater influence on Ca content in seeds in studies involving two crosses of $P$. vulgaris, with reported broad-sense heritability values of up to $74.6 \%$ (Jost et al., 2009).

Few of these studies analyzed genetic parameters in populations, simultaneously segregating for seed accumulation of a large set of essential minerals. Therefore, the major objective of the present study was to estimate key genetic parameters related to the levels of seed accumulation of six minerals ( $\mathrm{Zn}, \mathrm{Fe}, \mathrm{Ca}, \mathrm{P}, \mathrm{K}$, and $\mathrm{Na}$ ) in crosses of the inbred line IT97K-1042-3 and two contrasting cowpea genotypes. Clarification of the genetic control of higher accumulation levels of essential minerals in cowpea seeds is expected to provide methodological support necessary for the development of new genetically biofortified cowpea varieties that are more suitable for cultivation in Brazilian tropical semi-arid regions.

\section{MATERIAL AND METHODS}

\section{Plant material}

Seeds from six generations, including two contrasting parental lines, $\mathrm{F}_{1}, \mathrm{~F}_{2}$, and backcrosses to both parents, were obtained from two crosses: IT97K-1042-3 x BRS Tapaihum and IT97K-1042-3 x Canapu. The line IT97K-1042-3 [developed by the International Institute for Tropical Agriculture (IITA)] was employed in the present study, as a common parent in both crosses due to its high seed mineral content (Singh, 2007). One of the contrasting parental lines was BRS Tapaihum, which was developed by Embrapa Semiárido breeding program as a cultivar with black seed coat, determinate growth, and an upright plant habit. The other parental line was Canapu, which is a widespread Brazilian landrace with light brown seed color that has been selected and maintained by farmers from Piauí State, Brazil. Seeds of these genetic populations were sown on Styrofoam trays with one seed per cell. Six days after sowing, the plants were transplanted into the field with a spacing of $1.2 \times 0.10 \mathrm{~m}$. Drip irrigation and recommended crop practices for the cowpea cultivation in this geographical region were employed during the field assays.

\section{Quantification of $\mathrm{K}, \mathrm{Ca}, \mathrm{Fe}, \mathrm{Zn}, \mathrm{P}$, and Na contents in cowpea seeds}

Approximately $10 \mathrm{~g}$ seeds from each plant were ground in a mill MA 630/1 (Marconi Equipamentos para Laboratórios Ltda., Piracicaba, SP, Brazil) into fine flour. The flour samples were analyzed in duplicate following the protocol of the Association of Official Analytical Chemists (AOAC, 1995). Each sample $(500 \mathrm{mg})$ of dry cowpea beans was digested with $5 \mathrm{~mL}$ nitric acid and $1 \mathrm{~mL}$ perchloric acid in a block digester as the samples were gradually heated to $180^{\circ} \mathrm{C}$ for a period of three hours. Two extracts were prepared for mineral quantification. Extract A (for analysis of $\mathrm{P}, \mathrm{Fe}, \mathrm{Zn}, \mathrm{K}$, and $\mathrm{Na}$ ): After cooling of the digester tubes, $49 \mathrm{~mL}$ distilled and deionized water were added to each sample. $\mathrm{P}, \mathrm{Fe}$, and $\mathrm{Zn}$ were quantified in a flame atomic absorption photospectrometer (Varian 4000, Varian 
Inc., Palo Alto, CA, USA), and $\mathrm{K}$ and $\mathrm{Na}$ were quantified in a flame photometer (MicroNal, São Paulo, SP, Brazil). Extract B (for analysis of Ca): One milliliter of extract A was transferred to a $50-\mathrm{mL}$ beaker labeled with the corresponding protocol number of each sample. The total volume was adjusted by adding $49 \mathrm{~mL} 0.1 \%$ lanthanum oxide, and the samples were quantified in the flame atomic absorption photospectrometer. Mineral contents were expressed in $\mathrm{g} / \mathrm{kg}$ of seed dry matter for $\mathrm{Ca}, \mathrm{P}$, and $\mathrm{K}$ and in $\mathrm{mg} / \mathrm{kg}$ of seed dry matter for $\mathrm{Fe}, \mathrm{Zn}$, and $\mathrm{Na}$. All the analyses were carried out at the Soil Science Laboratory at Embrapa Semiárido, Petrolina, PE, Brazil.

\section{Genetic and statistical analyses}

Broad- and narrow-sense heritability were estimated from the averages and variances of the crosses IT97K-1042-3 x Canapu and IT97K-1042-3 x BRS Tapaihum as described by Mather and Jinks (1982). Additive genetic effects as well as the effects due to dominance deviation in mineral content were estimated by the weighted mean squares from the means of each generation in each cross (Mather and Jinks, 1982). All the estimates were carried out with the Genes software package (Cruz, 2006) using the segregating and non-segregating option of the biometric procedure. To estimate the genetic parameters and the minimum number of genes controlling the accumulation of minerals, the original data set for all minerals was transformed to a square root plus one, as recommended by Lande (1981).

\section{RESULTS}

Contrasting parental lines are a prerequisite to accurately estimate the number of genes and genetic parameters for a specific trait (Mather and Jinks, 1982). The seed mineral content of the three parental lines employed in our genetic analyses (IT97K-1042-3, BRS Tapaihum, and Canapu) varied for all six minerals evaluated (Table 1). The parental line IT97K-1042-3 was confirmed, under our experimental conditions, as an outstanding source of alleles for development of cowpea cultivars biofortified for seed mineral content. The line displayed an overall higher seed mineral content than BRS Tapaihum and Canapu. The mean differences between the parental lines indicated contrasting seed content values for $\mathrm{Ca}, \mathrm{Fe}$, and $\mathrm{P}$ as well as moderate differences for $\mathrm{K}$ and $\mathrm{Na}$. Contrasting values for Zn were observed only between the parents IT97K-1042-3 and BRS Tapaihum (Table 1). The variance values among the parental lines were comparable for all minerals, expect for $\mathrm{Zn}$ and $\mathrm{Na}$.

In the generation analyses, the largest variances were found in $\mathrm{F}_{2}$ populations of the two crosses for all minerals analyzed except $\mathrm{Na}$ (Table 1). This result was expected, since the largest segregation due to the maximum linkage disequilibrium occurs in the $\mathrm{F}_{2}$ generation (Mather and Jinks, 1982). Transgressive mineral accumulation values (superior to that of the best parental line) were observed in $\mathrm{F}_{2}$ individual plants for all minerals examined, except for Na in the cross IT97K-1042-3 x BRS Tapaihum (Table 2). These results strongly indicate that it is feasible to develop cultivars with superior levels of $\mathrm{Ca}, \mathrm{Zn}, \mathrm{Fe}$, and $\mathrm{K}$ using this germplasm, since some of the observed values were even higher than those reported by Singh (2007). 
Table 1. Content of six minerals in seeds of six generations derived from two crosses involving contrasting cowpea lines expressed as transformed and non-transformed averages by the square root +1 (Sqrt) and variances. Petrolina, PE, Brazil, 2011.

\begin{tabular}{|c|c|c|c|c|c|c|c|c|}
\hline \multirow[t]{4}{*}{ Minerals/Cross generations } & \multicolumn{8}{|c|}{ Crosses } \\
\hline & \multicolumn{4}{|c|}{ IT97K-1042-3 (P1) x Canapu (P2) } & \multicolumn{4}{|c|}{ IT97K-1042-3 (P1) x BRS Tapaihum (P2) } \\
\hline & $\mathrm{N}$ & Average & & Variance & $\mathrm{N}$ & Average & & Variance \\
\hline & & Normal & Sqrt & Sqrt & & Normal & Sqrt & Sqrt \\
\hline \multicolumn{9}{|l|}{ Calcium (g/kg) } \\
\hline P1 & 21 & 1.93 & 1.71 & 0.011 & 20 & 1.90 & 1.70 & 0.009 \\
\hline $\mathrm{P} 2$ & 35 & 1.29 & 1.51 & 0.015 & 31 & 1.18 & 1.47 & 0.007 \\
\hline $\mathrm{F} 1$ & 31 & 1.47 & 1.56 & 0.019 & 14 & 1.47 & 1.56 & 0.009 \\
\hline $\mathrm{F} 2$ & 203 & 1.12 & 1.45 & 0.027 & 138 & 1.24 & 1.49 & 0.026 \\
\hline $\mathrm{BC} 1$ & 20 & 0.62 & 1.27 & 0.002 & 37 & 1.47 & 1.56 & 0.007 \\
\hline $\mathrm{BC} 2$ & 84 & 1.11 & 1.45 & 0.011 & 25 & 1.61 & 1.60 & 0.028 \\
\hline \multicolumn{9}{|l|}{ Zinc (mg/kg) } \\
\hline $\mathrm{P} 1$ & 20 & 27.5 & 5.33 & 0.077 & 21 & 27.2 & 5.30 & 0.087 \\
\hline P2 & 30 & 27.9 & 5.35 & 0.195 & 34 & 30.7 & 5.63 & 0.063 \\
\hline $\mathrm{F} 1$ & 48 & 27.6 & 5.34 & 0.079 & 48 & 43.0 & 6.63 & 0.034 \\
\hline $\mathrm{F} 2$ & 202 & 28.6 & 5.41 & 0.219 & 134 & 32.1 & 5.72 & 0.319 \\
\hline $\mathrm{BC} 1$ & 18 & 34.3 & 5.94 & 0.084 & 37 & 44.9 & 6.77 & 0.037 \\
\hline $\mathrm{BC} 2$ & 85 & 31.2 & 5.66 & 0.106 & 30 & 28.7 & 5.42 & 0.292 \\
\hline \multicolumn{9}{|l|}{ Iron $(\mathrm{mg} / \mathrm{kg})$} \\
\hline $\mathrm{P} 1$ & 20 & 70.80 & 8.47 & 0.049 & 22 & 70.1 & 8.42 & 0.064 \\
\hline $\mathrm{P} 2$ & 39 & 53.82 & 7.40 & 0.043 & 34 & 51.4 & 7.23 & 0.078 \\
\hline $\mathrm{F} 1$ & 27 & 79.59 & 8.97 & 0.058 & 16 & 55.0 & 7.47 & 0.067 \\
\hline F2 & 198 & 67.16 & 8.23 & 0.373 & 137 & 55.7 & 7.51 & 0.199 \\
\hline $\mathrm{BC} 1$ & 18 & 70.06 & 8.42 & 0.171 & 32 & 56.7 & 7.58 & 0.177 \\
\hline $\mathrm{BC} 2$ & 85 & 48.31 & 7.01 & 0.147 & 30 & 55.9 & 7.53 & 0.111 \\
\hline \multicolumn{9}{|l|}{ Phosphorus (g/kg) } \\
\hline $\mathrm{P} 1$ & 19 & 5.80 & 2.60 & 0.005 & 19 & 5.79 & 2.60 & 0.005 \\
\hline $\mathrm{P} 2$ & 36 & 4.01 & 2.23 & 0.004 & 33 & 4.69 & 2.38 & 0.004 \\
\hline $\mathrm{F} 1$ & 45 & 4.47 & 2.34 & 0.004 & 16 & 4.48 & 2.34 & 0.003 \\
\hline $\mathrm{F} 2$ & 197 & 4.42 & 2.32 & 0.017 & 140 & 5.56 & 2.55 & 0.018 \\
\hline $\mathrm{BC} 1$ & 20 & 5.29 & 2.51 & 0.006 & 39 & 5.48 & 2.54 & 0.008 \\
\hline $\mathrm{BC} 2$ & 79 & 4.16 & 2.27 & 0.007 & 28 & 5.75 & 2.59 & 0.018 \\
\hline \multicolumn{9}{|l|}{ Potassium (g/kg) } \\
\hline $\mathrm{P} 1$ & 23 & 14.35 & 3.92 & 0.016 & 23 & 14.3 & 3.90 & 0.016 \\
\hline $\mathrm{P} 2$ & 38 & 16.70 & 4.20 & 0.015 & 35 & 17.2 & 4.30 & 0.017 \\
\hline $\mathrm{F} 1$ & 47 & 17.01 & 4.25 & 0.015 & 17 & 17.3 & 4.30 & 0.007 \\
\hline $\mathrm{F} 2$ & 199 & 18.07 & 4.35 & 0.067 & 141 & 15.1 & 4.00 & 0.102 \\
\hline $\mathrm{BC} 1$ & 19 & 18.18 & 4.38 & 0.010 & 38 & 18.1 & 4.40 & 0.018 \\
\hline $\mathrm{BC} 2$ & 79 & 17.73 & 4.3 & 0.042 & 32 & 14.2 & 3.90 & 0.093 \\
\hline \multicolumn{9}{|l|}{ Sodium (mg/kg) } \\
\hline $\mathrm{P} 1$ & 22 & 140.3 & 11.9 & 0.080 & 22 & 140.3 & 11.8 & 0.080 \\
\hline $\mathrm{P} 2$ & 34 & 116.7 & 10.8 & 0.264 & 19 & 162.6 & 12.7 & 0.513 \\
\hline $\mathrm{F} 1$ & 43 & 110.6 & 10.5 & 1.777 & 15 & 64.4 & 8.0 & 1.201 \\
\hline $\mathrm{F} 2$ & 204 & 105.5 & 10.2 & 1.912 & 137 & 59.2 & 7.7 & 1.649 \\
\hline $\mathrm{BC} 1$ & 20 & 105.6 & 10.3 & 0.086 & 36 & 55.9 & 7.4 & 1.538 \\
\hline $\mathrm{BC} 2$ & 84 & 91.2 & 9.5 & 1.476 & 31 & 83.8 & 9.2 & 0.758 \\
\hline
\end{tabular}

$\mathrm{N}$ indicates the number of individual plants; $\mathrm{BC} 1$ and $\mathrm{BC} 2$ indicate backcross 1 and backcross 2, respectively.

As expected, all the variances were positive with the exception of dominance variances, which showed negative values in close proximity to zero (Table 2). Negative variances have been reported by Barakat (1996) for wheat and by Hallauer et al. (2010) for maize. When negative dominance variance values are observed they are assumed to be equal to zero (Barakat, 1996), transforming the broad- and narrow-sense heritability values into the same value for all mineral contents. 
Broad- and narrow-sense heritability values were comparable for $\mathrm{P}, \mathrm{K}$, and $\mathrm{Na}$ in the two crosses. However, some discrepancies were observed between crosses for other minerals (Table 2). The highest broad- and narrow-sense heritability values were observed for Fe (86\%), $\mathrm{P}(77.9 \%)$, and $\mathrm{K}(88.3 \%)$ (Table 2), which indicates that increasing cowpea seed content for these minerals is a relatively straightforward breeding procedure. The largest discrepancy between heritability values in the two crosses was for $\mathrm{Zn}$ accumulation, probably due to the lack of significant difference between the parental lines IT97K-1042-3 and Canapu. Therefore, in the particular case of Zn, only the cross IT97K-1042-3 x BRS Tapaihum was considered. The observed heritability value (82.8\%) indicated that increasing the $\mathrm{Zn}$ seed content in cowpea cultivars is also a relatively simple breeding task.

Table 2. Estimates of genetic parameters for potassium, calcium, iron, zinc, and sodium in two cowpea populations, calculated as original data transformed by the square root +1 . Petrolina, PE, Brazil, 2011.

\begin{tabular}{|c|c|c|}
\hline \multirow[t]{2}{*}{ Minerals/Genetic parameters } & \multicolumn{2}{|c|}{ Crosses } \\
\hline & IT97K-1042-3 x Canapu & IT97K-1042-3 x BRS Tapaihum \\
\hline \multicolumn{3}{|l|}{ Calcium } \\
\hline Maximum value in $\mathrm{F}_{2}$ & 3.2 & 2.6 \\
\hline Genotypic variance & 0.011 & 0.012 \\
\hline Additive variance & 0.042 & 0.006 \\
\hline Dominance variance & -0.031 & 0.006 \\
\hline Broad/narrow heritability (\%) & 41.4 & 56.2 \\
\hline Number of genes* & 2.0 & 8.5 \\
\hline \multicolumn{3}{|l|}{ Zinc } \\
\hline Maximum value in $\mathrm{F}_{2}$ & 46.0 & 46.0 \\
\hline Genotypic variance $^{2}$ & 0.111 & 0.264 \\
\hline Additive variance & 0.247 & 0.308 \\
\hline Dominance variance & -0.136 & -0.043 \\
\hline Broad/narrow heritability (\%) & 50.8 & 82.8 \\
\hline Number of genes* & 3.2 & 1.9 \\
\hline \multicolumn{3}{|l|}{ Iron } \\
\hline Maximum value in $\mathrm{F}_{2}$ & 91.0 & 78.0 \\
\hline Genotypic variance ${ }^{2}$ & 0.321 & 0.129 \\
\hline Additive variance & 0.428 & 0.169 \\
\hline Dominance variance & -0.107 & -0.040 \\
\hline Broad/narrow heritability (\%) & 86.0 & 64.9 \\
\hline Number of genes* & 2.2 & 3.8 \\
\hline \multicolumn{3}{|l|}{ Phosphorus } \\
\hline Maximum value in $\mathrm{F}_{2}$ & 6.15 & 9.36 \\
\hline Genotypic variance $^{2}$ & 0.012 & 0.014 \\
\hline Additive variance & 0.020 & 0.010 \\
\hline Dominance variance & -0.007 & 0.004 \\
\hline Broad/narrow heritability (\%) & 73.7 & 77.9 \\
\hline Number of genes* & 2.9 & 10.4 \\
\hline \multicolumn{3}{|l|}{ Potassium } \\
\hline Maximum value in $\mathrm{F}_{2}$ & 21.5 & 18.1 \\
\hline Genotypic variance & 0.052 & 0.089 \\
\hline Additive variance & 0.083 & 0.092 \\
\hline Dominance variance & -0.031 & -0.002 \\
\hline Broad/narrow heritability (\%) & 76.8 & 88.3 \\
\hline Number of genes* & 2.3 & 1.53 \\
\hline \multicolumn{3}{|l|}{ Sodium } \\
\hline Maximum value in $\mathrm{F}_{2}$ & 146.9 & 93.9 \\
\hline Genotypic variance $^{2}$ & 0.948 & 0.901 \\
\hline Additive variance & 2.262 & 1.003 \\
\hline Dominance variance & -1.314 & -0.103 \\
\hline Broad/narrow heritability (\%) & 49.6 & 54.6 \\
\hline Number of genes* & 2.0 & 3.0 \\
\hline
\end{tabular}

*Based on variance values. 
The estimates of the number of genes were comparable in both crosses for all minerals analyzed, except $\mathrm{Ca}$ (Table 2). The estimates indicated that the number of genes controlling the mineral accumulation traits varied from 1.5 for $\mathrm{K}$ to 10.4 for $\mathrm{P}$, suggesting that the development of cultivars with high levels of minerals is manageable.

The analyses indicated the importance of the average effect of parental lines for all analyzed minerals. Coefficients of determination were greater than $68 \%$ in the two cowpea crosses, except for $\mathrm{Zn}$. Important additive effects were observed for $\mathrm{Ca}, \mathrm{Fe}, \mathrm{P}, \mathrm{K}$, and $\mathrm{Na}$, while effects due to epistasis were important for Zn (Table 3).

Table 3. Non-orthogonal decomposition of the sum of the roots (QM) of parameters by the Gaussian elimination method for the content of six minerals in two crosses between cowpea lines using data of six generations: parental lines, $\mathrm{F}_{1}, \mathrm{~F}_{2}$, and backcross populations. Petrolina, PE, Brazil, 2011.

\begin{tabular}{|c|c|c|c|c|}
\hline \multirow[t]{3}{*}{ Minerals/variance source } & \multicolumn{4}{|c|}{ Crosses } \\
\hline & \multicolumn{2}{|c|}{ IT97K-1042-3 x Canapu } & \multicolumn{2}{|c|}{ IT97K-1042-3 x BRS Tapaihum } \\
\hline & $\mathrm{QM}$ & $\mathrm{R}^{2}$ & QM & $\mathrm{R}^{2}$ \\
\hline \multicolumn{5}{|l|}{ Calcium } \\
\hline M & 1153.60 & 67.6 & 181.52 & 59.1 \\
\hline A & 42.12 & 2.5 & 72.77 & 23.7 \\
\hline $\mathrm{D}$ & 136.80 & 8.0 & 10.91 & 3.6 \\
\hline $\mathrm{Aa}$ & 38.47 & 2.3 & 19.83 & 6.5 \\
\hline $\mathrm{Ad}$ & 167.47 & 9.8 & 15.12 & 4.9 \\
\hline Dd & 168.62 & 9.9 & 6.91 & 2.3 \\
\hline \multicolumn{5}{|l|}{ Zinc } \\
\hline M & 331.17 & 58.9 & 193.20 & 41.1 \\
\hline A & 0.06 & 0.1 & 17.59 & 3.7 \\
\hline D & 77.19 & 13.7 & 33.31 & 7.1 \\
\hline $\mathrm{Aa}$ & 56.67 & 10.0 & 26.79 & 5.7 \\
\hline $\mathrm{Ad}$ & 9.59 & 1.7 & 187.31 & 39.8 \\
\hline Dd & 87.15 & 15.0 & 12.32 & 2.6 \\
\hline \multicolumn{5}{|l|}{ Iron } \\
\hline M & 1318.99 & 68.0 & 1079.56 & 77.7 \\
\hline A & 319.09 & 16.4 & 274.24 & 19.7 \\
\hline D & 68.69 & 3.5 & 0.34 & 0.1 \\
\hline $\mathrm{Aa}$ & 57.12 & 2.9 & 0.63 & 0.1 \\
\hline $\mathrm{Ad}$ & 63.04 & 3.2 & 34.02 & 2.4 \\
\hline $\mathrm{Dd}$ & 113.97 & 5.9 & 0.22 & 0.1 \\
\hline \multicolumn{5}{|l|}{ Phosphorus } \\
\hline M & 1504.38 & 77.8 & 1091.00 & 85.1 \\
\hline A & 381.61 & 19.7 & 129.71 & 10.1 \\
\hline D & 10.55 & 0.5 & 7.44 & 0.6 \\
\hline $\mathrm{Aa}$ & 22.31 & 1.2 & 0.38 & 0.1 \\
\hline $\mathrm{Ad}$ & 5.40 & 0.3 & 27.85 & 2.0 \\
\hline Dd & 10.02 & 0.5 & 25.49 & 1.9 \\
\hline \multicolumn{5}{|l|}{ Potassium } \\
\hline M & 1672.33 & 93.3 & 500.85 & 67.9 \\
\hline A & 74.97 & 4.1 & 103.33 & 14.0 \\
\hline D & 12.90 & 0.7 & 5.84 & 0.8 \\
\hline $\mathrm{Aa}$ & 0.11 & 0.1 & 10.81 & 1.5 \\
\hline $\mathrm{Ad}$ & 29.51 & 1.6 & 115.28 & 15.6 \\
\hline Dd & 22.17 & 1.2 & 1.23 & 0.2 \\
\hline \multicolumn{5}{|l|}{ Sodium } \\
\hline M & 657.78 & 78.3 & 201.30 & 69.1 \\
\hline A & 95.74 & 11.4 & 25.73 & 8.8 \\
\hline D & 36.68 & 4.4 & 12.89 & 4.4 \\
\hline $\mathrm{Aa}$ & 6.20 & 0.7 & 14.80 & 5.1 \\
\hline $\mathrm{Ad}$ & 3.05 & 0.4 & 21.83 & 7.5 \\
\hline Dd & 40.18 & 4.7 & 14.60 & 5.0 \\
\hline
\end{tabular}

$\mathrm{M}=$ parental effect, $\mathrm{A}=$ additive effect, $\mathrm{D}=$ dominance effect, $\mathrm{Aa}, \mathrm{AD}, \mathrm{Dd}=$ epistasis effect. 


\section{DISCUSSION}

Cowpea is a strategic pulse crop in the Brazilian semi-arid region due to its low production costs and adaptation to cultivation under water-stressed conditions (Freire-Filho, 2011). The introduction of biofortified agricultural products and crop varieties with superior nutritional value is an important low cost strategy for increasing the food sustainability. Genetic approaches are currently being applied in many crop plants aiming to biofortify food crops with essential mineral elements most commonly lacking in human diets such as $\mathrm{Fe}, \mathrm{Zn}$, $\mathrm{Cu}, \mathrm{Ca}, \mathrm{Mg}$, iodine (I), and selenium (Se) (for review see White and Broadly, 2009). However, current efforts to develop cowpea cultivars with high mineral content associated with good agronomic performance are still very restricted. These improved and locally adapted cowpea cultivars would be a valuable contribution especially in geographic areas under the risks of mineral malnutrition such as the Brazilian semi-arid region (Rios et al., 2009).

To our knowledge, the present study is the broadest study conducted so far on genetic parameters responsible for mineral accumulation in cowpea seeds. The information generated here will be useful for genetic improvement programs aiming to increase the content of minerals in this legume. Broad- and narrow-sense heritability values ranged from moderate to high for all minerals in all crosses examined, which indicates that genetic effects are the largest component of the phenotypic expression of these traits in cowpea and that the prospects for cultivar improvement can be obtained with relative ease.

The average effect of the parental lines and the additive effects were the most important components, suggesting that the increase in mineral values can be obtained through methods of genealogical improvement and "single pod descent", the most commonly applied breeding methods in autogamous plants such as cowpea (Ntare et al., 1984). The crossing of divergent parents with high mineral content is also recommended because the average effect of the parental lines contributes significantly to the gene expression models. Apart from polygenic nature of the mineral content in cowpea, the number of genes had not increased; it varied from two to less than 11 in the two examined crosses. This correlation between the number of genes and mineral content can be assessed with genome mapping studies, and it will be the foundation of a marker assisted selection platform aiming to develop cowpea cultivars with high mineral contents.

In contrast to the results presented here, Ojo et al. (2006) reported non-additive gene action (dominance and epistasis) for P content in the genetic analysis of the generations from the cross IT90K-277-2 x IT89D-288. However, the authors reported narrow-sense heritability of $50.5 \%$, which is less than our estimated values for the two cowpea crosses (73.7 and $77.9 \%$ ). Zaiter et al. (1988), based on the regression of $\mathrm{F}_{3}$ means, reported narrow-sense heritability estimates for Fe in individual $\mathrm{F}_{2}$ plants in the range from 0.29 to 0.75 for an array of 13 P. vulgaris crosses. Rosa (2009) reported narrow-sense heritability for $\mathrm{Zn}$ of 77.8 and $57.5 \%$ in genetic analyses of segregating and non-segregating generations of $P$. vulgaris, respectively. Furthermore, this author reported transgressive segregation for $\mathrm{P}$ and $\mathrm{Zn}$ contents in the same study. Jost et al. (2009) stated high broad-sense heritability value (74.6\%) for Ca content in two crosses of $P$. vulgaris and greater additive genetic effect. Although these values were observed for distinct species and populations, they suggest that the increase of seed minerals in leguminous crops can be achieved with certain ease. Moderate and increased values were reported for heritability, although this genetic parameter is specific to the examined segregating generations. 
High heritability values, presence of the average effect of the parental lines, contribution of additive effects, and reduced number of associated genes strongly indicate that increasing the levels of all six minerals can be a relatively straightforward procedure. This combination of positive features suggests that the seed mineral contents can be improved with standard breeding methods largely used in autogamous plants.

The maximum dry matter accumulation values reported by Boukar et al. (2011) for $\mathrm{Ca}, \mathrm{Zn}, \mathrm{Fe}, \mathrm{P}$, and $\mathrm{K}$ were $1.395,58,79.5,6.750$, and $18.450 \mathrm{mg} / \mathrm{kg}$, respectively, after examining a collection of 1541 accessions of cowpea. These seed mineral content values, with the exception of $\mathrm{Zn}$, were lower than the maximum values of some transgressive $\mathrm{F}_{2}$ individuals analyzed in the present study. Therefore, it is reasonable to assume that the mineral contents in cowpea can be increased far above the maximum that has been reported for this legume.

Crop seeds usually contain very low levels of bioavailable Fe and $\mathrm{Zn}$ (about $5 \%$ of total $\mathrm{Fe}$ and $25 \%$ of total $\mathrm{Zn}$ ). Improved cultivars that will be able to increase the levels of bioavailable Fe from 5 to $20 \%$ would have an impact equivalent to 4 -fold increase of the total amount of this mineral (Bouis and Welch, 2010). These results emphasize the significance of the increase of minerals in cowpea seeds via classical genetic approaches.

This new generation of nutritionally-rich cowpea cultivars adapted for the Brazilian semi-arid region can be one component that might help alleviate and/or minimize mineral deficiency (especially $\mathrm{Zn}$ and $\mathrm{Fe}$ ), which is a persistent problem for human population living within this geographic area (Costa et al., 2011).

\section{ACKNOWLEDGMENTS}

We would like to express our gratitude to the Conselho Nacional de Desenvolvimento Científico e Tecnológico (CNPq) for the financial support (grant \#306521/2013-0).

\section{REFERENCES}

Association of Official Analytical Chemists (AOAC) (1995). Method 920.87 - Protein (total) in flour, final action. In: Official Methods of Analysis of the Association of Official Analytical Chemists (Cunniff P, ed.). AOAC, Arlington, 12-13.

Barakat MN (1996). Estimation of genetic parameters for in vitro traits in wheat immature embryo cultures involving high $\mathrm{x}$ low regeneration capacity genotypes. Euphytica 87: 119-125.

Bouis HE and Welch RM (2010). Biofortification-A sustainable agricultural strategy for reducing micronutrient malnutrition in the global South. Crop Sci. 50: S20-S32.

Boukar O, Massawe F, Muranaka S, Franco J, et al. (2011). Evaluation of cowpea germplasm lines for protein and mineral concentrations in grains. Plant Genet. Resour. 9: 515-522.

Brown JC and Wann EV (1982). Breeding for iron efficiency. Use of indicator plants. J. Plant Nutr. 5: 623-635.

Costa EC, Silva SPDO, Lucena JRMD, Batista-Filho M, et al. (2011). Food consumption of children from cities with a low human development index in the Brazilian Northeast. Rev. Nutr. 24: 395-405.

Coyne DP, Korban SS, Knudsen D and Clark RB (1982). Inheritance of iron deficiency in crosses of dry beans (Phaseolus vulgaris L.). J. Plant Nutr. 5: 575-585.

Cruz CD (2006) Programa Genes: Biometria. 1st. edn. Editora UFV, Viçosa, 382.

Food and Agriculture Organization (FAO) (2011). FAOSTAT - Production/Crops. Available at [http://faostat3.fao.org/ browse/Q/QC/E]. Accessed May 7, 2014

Freire-Filho FR (2011) Feijão-caupi no Brasil: Produção, melhoramento genético, avanços e desafios. Embrapa MeioNorte, Teresina.

Hallauer AR, Carena MJ and Miranda Filho JB (2010). Quantitative genetics in maize breeding. 3rd edn. Springer, New York, 169-170. 
Jost E, Ribeiro ND, Maziero SM, Cerutti T and Rosa DP (2009). Genetic effects of the calcium content in common bean. Cienc. Rural 39: 31-37.

Lande R (1981). The minimum number of genes contributing to quantitative variation between and within populations. Genetics 99: 541-553.

Mather K and Jinks JL (1982) Biometrical genetics, the study of continuous variation. 3rd edn. Chapman and Hall, London, New York.

Ntare BR, Aken'Ova ME, Redden RJ and Singh BB (1984). The effectiveness of early generation $\left(\mathrm{F}_{3}\right)$ yield testing and the single seed descent procedures in two cowpea (Vigna unguiculata (L.) Walp.) crosses. Euphytica 33: 539-547.

Ojo DK, Bodunde JG, Ogunbayo AS and Aknwale AF (2006). Genetics evaluation of phosphorus utilization in tropical cowpea (Vigna unguiculata (L) Walp). Afr. J. Biotechnol. 5: 597-602.

Ribeiro ND, Jost E, Cerutti T, Mazieiro SM, et al. (2008). Composição de microminerais em cultivares de feijão e aplicações para o melhoramento genético. Bragantia 67: 267-273.

Rios AS, Alves KR, Costa NMB and Martino HSD (2009). Biofortificação: culturas enriquecidas em micronutrientes pelo melhoramento genético. Rev. Ceres 56: 713-718.

Rosa SS (2009). Genética dos teores de fósforo e de zinco em sementes de feijão. Master's thesis. Universidade Federal de Santa Maria, Santa Maria.

Santos CAF and Boiteux LS (2013). Breeding biofortified cowpea lines for semi-arid tropical areas by combining higher seed protein and mineral levels. Genet. Mol. Res. 12: 6782-6789.

Santos CAF, Costa DCC, Silva WR and Boiteux LS (2012). Genetic analysis of total seed protein content in two cowpea crosses. Crop Sci. 52: 2501-2506.

Singh BB (2007). Recent progress in cowpea genetics and breeding. Acta Hortic. 752: 69-76.

White PJ and Broadley MR (2009). Biofortification of crops with seven mineral elements often lacking in human dietsiron, zinc, copper, calcium, magnesium, selenium and iodine. New Phytol. 182: 49-84.

Zaiter HZ, Coyne DP and Clark RB (1988). Genetic variation, heritability, and selection response to iron deficiency chlorosis in dry beans. J. Plant Nutr. 11: 739-746. 